\title{
PENGARUH VARIASI SEMEN TERHADAP NILAI CBR BASE PERKERASAN LENTUR TIPE CEMENT TREATED BASE (CTB)
}

\author{
Herman $^{1}$ dan Jon Edwar ${ }^{2}$
}

\begin{abstract}
ABSTRAK
Dalam mengantisipasi pertumbuhan volume lalu lintas kedaraan berat pada daerah industri dan pelabuhan, lapisan base tipe Cement Treated Base (CTB) merupakan alternative yang dapat digunakan untuk menggantikan perkerasan tipe Asphalt Treated Base (ATB). Untuk mengetahui pengaruh semen terhadap base, diadakanlan penelitian dilaboratorium UPTD. Balai Pengujian bahan DPU. Padang, sampel base yang digunakan tipe Klas A diambil dari stokfile Angkasa Teknik Raya, semen digunakan semen Padang Tipe I, penambahan semen adalah $0 \%, 3 \%, 5 \%$ dan $7 \%$ dari berat kering campuran base dengan masa perawatan 3 hari. Pengujian yang dilakukan adalah uji sifat fisis dan uji sifat mekanis. Uji sifat fisis terdiri dari uji berat jenis, kadar air, dan analisa saringan sedangkan uji sifat mekanis terdiri dari uji pemadatan dan uji CBR baik dengan rendaman maupun tidak terendam dengan masa perawatan 3 hari. Hasil penelitian menunjukan meningkatnya persentase semen pada base, nilai kadar air optimum juga meningkat, sedangkan nilai kepadatan maksimum ( $\gamma d$ maks), dan CBR ( terendam dan tidak terendam), pada awalnya nilai-nilai inimeningkat (sampai pada campuran base $+3 \%$ semen), seiring dengan peningkatan persentase semen pada base, nilai-nilai ini cenderung menurun.
\end{abstract}

Kata kunci : cement treated base, aspal treated base, stok file, CBR, optimum

\section{PENDAHUluan}

Cement Treated Base (CTB) adalah lapis pondasi (base course) pada perkerasan lentur (flexible pavement) dan merupakan pengembangan dari pondasi soil cement. Walaupun cara pembuatan dan hasil akhirnya berupa beton, namun CTB bukan merupakan pengembangan dari rigid pavement. Dalam mengantisipasi kerusakan jalan akibat pertumbuhan volume lalu lintas kendaraan berat pada daerah industri dan pelabuhan, perkerasan tipe CTB merupakan alternatif yang dapat digunakan untuk menggantikan perkerasan tipe Asphalt Treated Base (ATB).

Penggunaan cement sebagai bahan pengikat pengganti aspal pada perencanaan perkerasan lentur juga didasarkan pada nilai ekonomis dimana akhir-akhir ini harga aspal meningkat tajam, masalah yang dihadapi dalam penggunaan CTB di Indonesia adalah belum adanya standart yang ditentukan. AASTHO 1986, mensyaratkan pengujian CTB dengan pengujian Unconfined Compresive Strength (UCS) pada benda uji berbentuk silinder diameter $7,1 \mathrm{~cm}$ dengan tinggi $14,2 \mathrm{~cm}$. Ukuran benda uji ini tidak umum digunakan di Indonesia. Persyaratan untuk lapis pondasi dengan menggunakan bahan pengikat semen harus memiliki CBR 100\%, yaitu setara dengan lapis pondasi Klas A.

\footnotetext{
${ }^{1}$ Staf Pengajar Jurusan Teknik Sipil Fakultas Teknik Sipil dan Perencanaan Institut Teknologi Padang

${ }^{2}$ Mahasiswa Jurusan Teknik Sipil Fakultas Teknik Sipil dan Perencanaan Institut Teknologi Padang
} 


\section{STUDI LITERATUR}

Kezdi, A. 1979, stabilitas kimiawi dapat merubah struktur tanah dengan terbentuknya butiranbutiran agregat yang lebih menguntungkan. Stabilitas tanah secara kimiawi merupakan suatu proses yang dilakukan dengan bahan tambahan yang berfungsi untuk memperbaiki kualitas tanah dasar agar mampu menahan beban yang bekerja diatasnya. Bowless, JE. 1986, stablisasi tanah dengan menggunakan bahan kapur, abu batubara, semen pada suatu deposit lempung, dapat menurunkan nilai indeks plastisitas (PI) tanah, nilai batas cair (LL), pengembangan atau penyusutan tanah yang cukup berarti.

Sifat-sifat tanah dasar untuk sub-grade dikelompokan berdasarkan plastisitas dan ukuran butirnya. Daya dukung tanah dapat diperkirakan dengan mempergunakan hasil klasifikasi pembebanan plat uji ataupun dari pemeriksaan CBR (Sukirman, S 1992). Mitchel JK. (1992), melakukan pengujian dan mencoba mengontrol ukuran, bentuk butiran, sifat fisik dan sifat kimia partikel tanah. Tanah lempung (clay) mempunyai karakteristik atau bersifat plastis, mempunyai daya dukung yang cukup besar dalam kondisi kering dan tereduksi besar apabila dalam kondisi basah, permukaan kelihatan halus dan mengkilat jika digosok dalam kondisi kering, bersifat koloid didalam air. Damoerin dan Virisdiyanto (1999), melaporkan bahwa penambahan pasir dan semen atau kapur pada tanah lempung ekspansif, menunjukan perbaikan sifat fisis dan sifat teknis tanah lempung berupa turunnya nilai indeks plastisitas, potensi dan tekanan pengembangan, dan meningkatnya nilai CBR dan kuat tekan bebas tanah.

Naatonis F. dan Candra I (1998), melakukan penelitian mengenai penggunaan campuran tanah asli dan semen untuk menggantikan fungsi material aggregat pada lapisan pondasi jalan, tujuan penelitian untuk mengetahui seberapa besar peningkatan nilai daya dukung tanah asli dicampur dengan semen, disamping banyaknya kadar semen dan lamanya waktu curing yang efektif untuk mendapatkan kekuatan dan kondisi campuran tanah asli dan semen yang memenuhi persyaratan sebagai bahan konstruksi jalan. Percobaan dilakukan dengan beberapa prosentase semen, yaitu 3\%, $4 \%, 6 \%, 8 \%, 10 \%$ dan $12 \%$. Pengujian yang dilakukan antara lain spesific gravity, liquit limit, plastic limit, shringkage limit, permeability test, california bearing ratio, dan unconfined compressive strength test. Hasil penelitian menunjukan bahwa penambahan semen pada tanah asli dapat meningkatkan nilai CBR, kuat tekan bebas dan menurunkan shringkage dan permeabilitas. Nilai CBR dan kuat tekan bebas yang dihasilkan memenuhi persyaratan untuk lapisan pondasi jalan.

Pemadatan merupakan metode yang sering digunakan untuk memperbaiki kondisi tanah yang sifatnya sangat jelek, selain itu juga dapat dilakukan dengan menambah material yang lebih baik untuk mempertinggi nilai daya dukung tanah. Penelitian yang dilakukan oleh Rachmansyah A. dkk (2008), dengan penambahan pasir dengan variasi kadar air pemadatan terhadap nilai CBR pada tanah kaolin. Prosentase penambahan pasir 0\%, 20\%, 40\%, 60\% terhadap berat campuran tanah, sedangkan variasi kadar air berada disekitar OMC yaitu $-10 \%,-5 \%, 0 \%$ (OMC), dan $+5 \%$ dari OMC. Hasil penelitian memperlihatkan dengan penambahan pasir, nilai CBR meningkat. Penambahan pasir berpengaruh pada perubahan kadar air optimum dan berat isi kering. Semakin banyak pasir ditambahkan menyebabkan semakin sedikit jumlah air yang dibutuhkan untuk mencapai berat isi kering maksimum. Penambahan kadar air nilai CBR tanah mengecil, sebaliknya semakin sedikit kadar air nilai CBR campuran tanah bertambah besar. Hasil penelitian menunjukan penambahan prosentase pasir dan pengurangan kadar air dapat meningkatkan nilai CBR tanah.

\section{LANDASAN TEORI}

Berdasarkan bahan pengikatnya, konstruksi jalan dapat dibedakan ; 
1. Konstruksi perkerasan lentur (flexible pavement), yaitu perkerasan yang menggunakan aspal sebagai bahan pengikat, lapisan-lapisan bersifat memikul dan menyebarkan beban lalu lintas ke tanah dasar.

2. Konstruksi perkerasan kaku (rigid pavement) yaitu perkerasan yang menggunakan semen sebagai bahan pengikat, plat beton atau tanpa tulangan diletakan diatas diatas tanah dasar dengan atau tanpa lapis pondasi bawah, beban lalu lintas dipikul oleh plat beton.

3. Konstruksi perkerasan komposit (composite pavement), yaitu perkerasan kaku yang dikombinasikan dengan perkerasan lentur dapat berupa perkerasan lentur diatas perkerasan kaku atau perkerasan kaku diatas perkerasan lentur.

Untuk memberi rasa aman dan nyaman kepada pengguna jalan, konstruksi perkerasan jalan harus memenuhi beberapa syarat-syarat tertentu sebagai berikut ;

1. Syarat-syarat lalu lintas. Konstruksi perkerasan lentur dipandang dari keamanan dan kenyamanan berlalu lintas harus memenuhi syarat-syarat sebagai berikut ;

a. Memiliki permukaan yang rata, tidak berlubang, tidak melendut, dan tidak bergelombang

b. Permukaan cukup kaku, sehingga tidak mudah berubah bentuk akibat beban yang bekerja diatasnya.

c. Permukaan cukup kesat, memberikan gesekan yang baik antara ban dan permukaan jalan, sehingga tidak mudah slip.

d. Permukaan tidak mengkilap, tidak silau jika terkena matahari.

2. Syarat-syarat kekuatan/struktural. Konstruksi perkerasan jalan dipandang dari segi kemampuan memikul dan menyebarkan beban, harus memenuhi syarat-syarat sebagai berikut ;

a. Memiliki ketebalan yang cukup sehingga mampu menyebarkan beban, muatan lalu lintas ketanah dasar.

b. Kedap terhadap air, sehingga air tidah mudah meresap kelapisan bawahnya.

c. Permukaan mudah mengalirkan air , sehingga air hujan jatuh diatasnya dapat cepat dialirkan.

d. Kekakuan untuk memikul beban yang bekerja tanpa menimbulkan deformasi yang berarti.

Untuk dapat memenuhi syarat-syarat tersebut diatas, perencanaan dan pelaksanaan konstrusi perkerasan lentur jalan harus mencakup beberapa hal yaitu ;

1. Perencanaan tebal masing-masing perkerasan yaitu dengan memperhatikan daya dukung tanah dasar, beban lalu lintas yang dipikul, keberadaan lingkungan, dan jenis lapisan yang dipilih.

2. Analisa campuran bahan / material, dengan memperhatikan mutu dan jumlah bahan setempat yang tersedia.

3. Pengawasan pelaksanaan pekerjaan.

Secara umum lapisan konstrusi perkerasan terdiri dari lapisan permukaan (surfase course), lapisan pondasi atas (base course), lapisan pondasi bawah (sub base course), dan lapisan tanah dasar (sub grade). Kapasitas daya dukung tanah dasar dapat diperkirakan dengan menggunakan hasil klasifikasi atau hasil pemeriksaan CBR, pembebanan plat uji, dan sebagainya.

\subsection{Bahan Agregat Yang Digunakan}

\section{Agregat Batuan}

Aggregat kasar yang terdiri dari ;

$20-30 \mathrm{~mm}$

$10-20 \mathrm{~mm}$

$5-10 \mathrm{~mm}$

Aggregat halus yang terdiri dari,

$0-5 \mathrm{~mm}$ 


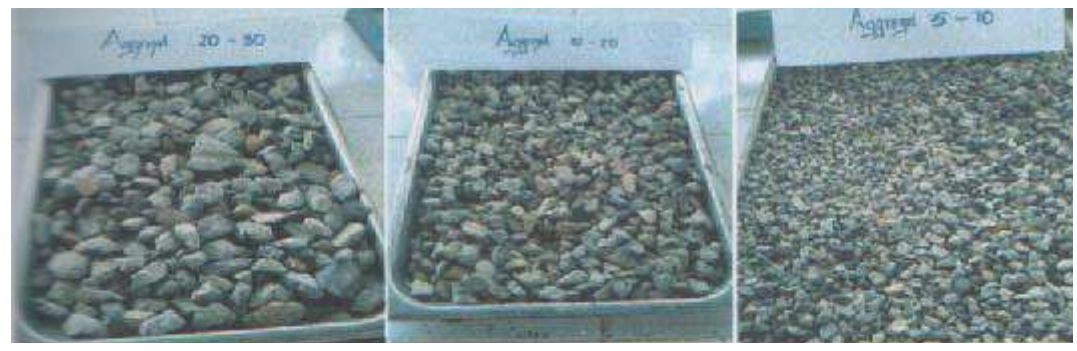

Gambar 1. Aggregat kasar

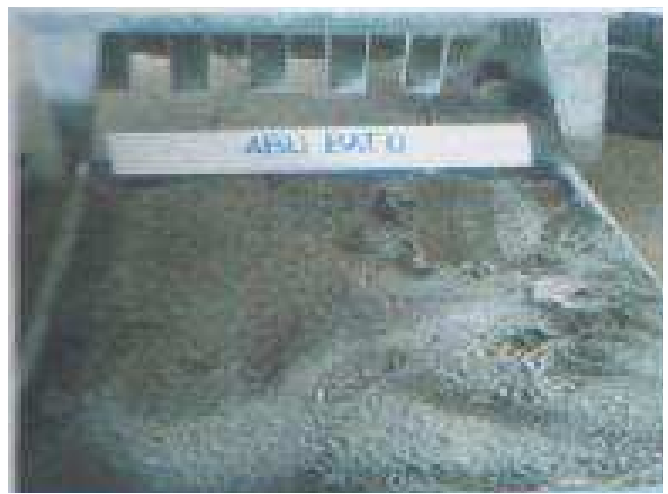

Gambar 2. Aggregat halus

\section{Semen Portland}

Semen portland yang digunakan dari merek yang sudah lazim dipakai dan memenuhi persyaratan ASTM C (Semen Type 1). Untuk mementukan Job Mix Formula (JMF) aggregat kasar dan aggregat halus digunakan spesifikasi Bina Marga (Tabel 1).

Tabel 1. Spesifikasi aggregat kasar dan aggregat halus pada base umum.

\begin{tabular}{|l|l|l|l|}
\hline \multicolumn{2}{|c|}{ Aggregat Kasar } & \multicolumn{2}{c|}{ Aggregat Halus } \\
\hline $\begin{array}{l}\text { Ukuran } \\
\text { Saringan }\end{array}$ & Spek & Ukuran Saringan & \% Lolos \\
\hline $1,5 "$ & 100 & no. 4 & $29-44$ \\
\hline $1 "$ & $79-85$ & no. 10 & $17-30$ \\
\hline $3 / 8 "$ & $44-58$ & no. 200 & $2-8$ \\
\hline
\end{tabular}

Syarat-syarat aggregat yang dipakai ;

a. Aggregat yang dipakai dari batu pecah, dari pemecahan batu alam

b. Gravel yang dipecah atau tidak dipecah harus merupakan batuan yang keras, tahan terhadap keausan, memenuhi kwalitas, gradasi, tidak pipih, memanjang dan bebas dari kotoran.

c. Metoda yang dipakai untuk menghasilkan batu pecah harus dapat menghasilkan produksi yang konsisten, bila perlu hasil pemecahan disaring terlebih dahulu.

Air

Air yang dipakai untuk mencampur adukan harus bersih, tidak mengandung minyak, lumpur, asam, bahan organik, alkali, garam, dan kotoran lain yang bersifat merusak campuran base.

\subsection{Sifat-sifat Fisis Agregat}

\section{Kadar Air Agregat}

Kadar air didefinisikan sebagai perbandingan berat air (Ww) dengan berat butiran (Ws) dalam campuran aggerat dinyatakan dalam persen.

\section{4 | JURNAL REKAYASA SIPIL}




$$
\mathrm{w}(\%)=\frac{\mathrm{Ww}}{\mathrm{Ws}} \times 100
$$

\section{Berat jenis (spesific gravity)}

Berat jenis aggeragat kasar dapat dihitung dengan ;

$$
S g \cdot a p=\frac{C}{C-B}
$$

dengan,

$$
\begin{array}{ll}
\text { Sg.ap } & =\text { berat jenis } \\
\mathrm{B} & =\text { berat contoh ssd dalam air } \\
\mathrm{C} & =\text { berat contoh kering }
\end{array}
$$

Berat jenis aggregat halus dapat dihitung dengan,

$$
\text { Sg.ap }=\frac{G}{G-(E-F)}
$$

dengan,

$$
\begin{array}{ll}
\text { Sg.ap } & =\text { berat jenis } \\
\text { G } & =\text { berat benda uji } \\
\text { D } & =\text { berat benda uji ssd } \\
\text { E } & =\text { berat pikno + air + benda uji }
\end{array}
$$

\section{Gradasi butiran}

Dimaksudkan untuk menentukan pembagian butiran aggregat halus dan aggregat kasar. Ada dua cara untuk menganalisis ukuran aggregat ;

a. Analisa saringan menggunakan saringan 1,5", 1", 3/8" (butiran kasar)

b. Analisa saringan dengan menggunakan ukuran no. 4, no.10. no. 40, no. 200 (butiran halus)

Setelah masing-masing aggregat diperiksa pembagian butirnya, dilakukanlah kombinasi campuran aggregat. Campuran aggregat ini sesuai dengan spesifikasi yang telah ditentukan. Setelah itu aggregat yang telah memenuhi spesifikasi dilakukanlah pengambilan sampel untuk uji pemadatan dan uji CBR.

\subsection{Sifat-sifat Mekanis Agregat}

\section{Percobaan Pemadatan}

Percobaan ini untuk menentukan kadar air optimum dan berat isi kering maksimum. Ada dua jenis pemadatan yang biasa digunakan yaitu,

a. Standar compaction

b. Modified compaction

Bila kadar air campuran aggregat rendah, maka aggregat kaku dan sukar dipadatkan, jika ditambahkan air, maka air berlaku sebagai pelumas sehingga campuran aggregat lebih mudah dipadatkan, jika penambahan air terlalu banyak, maka nilai kepadatan akan turun, karena pori-pori tanah terisi penuh dengan air. Berdasarkan kondisi diatas dilakukanlah 5 kali percobaan dengan kadar air yang bervariasi, hasilnya adalah kadar air (w) dan berat isi kering $(\gamma \mathrm{d})$ yang bervariasi pula, nilai-nilai ini di plot pada kurva hubungan antara kadar air pada absis dan berat isi kering 
pada ordinat. Nilai berat isi kering maksimum adalah terdapat pada puncak kurva, nilai ini akan berpadanan dengan kadar air optimum pada absis.

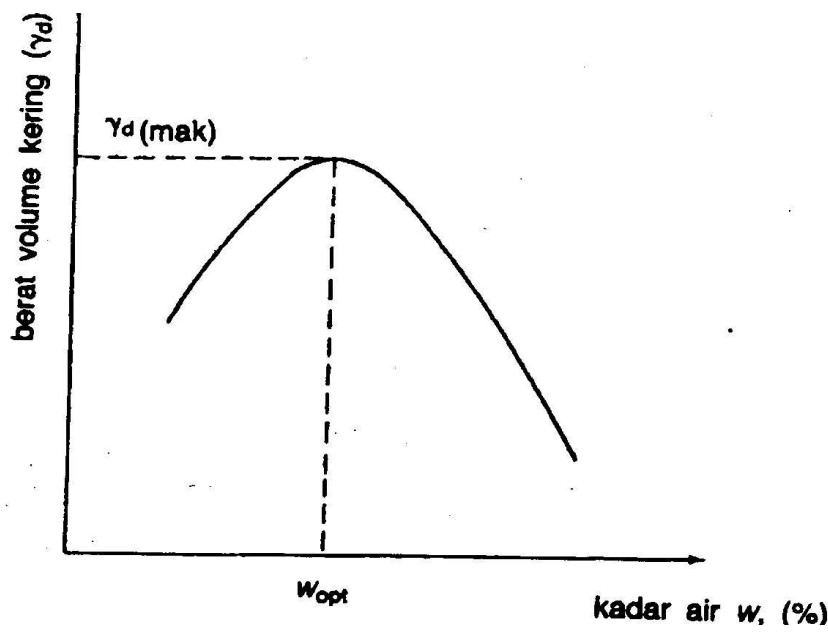

Gambar 3. Hubungan kadar air dengan berat isi kering

\section{CBR Laboratorium}

Setelah nilai berat isi kering maksimum dan kadar air optimum diperoleh, selanjutnya dibuat benda uji untuk uji CBR. Pemadatan dilakukan sesuai dengan ketentuan untuk uji CBR, sampel CBR dibuat dua buah, yang satu diuji tanpa perendaman, yang lain sebelum di uji dilakukan perendaman selama 4 hari. Setiap hari pada jam-jam yang telah ditentukan, dilakukanlah pencatatan tentang pengembangan sampel. Pengujian dilakukan dengan alat uji CBR, hasilnya adalah nilai CBR dari masing-masing benda uji.

\section{METODOLOGI}

Bahan pengujian berupa Base A dari stok file Angkasa Teknik Raya, semen tipe I dari Semen Padang, air bersih yang digunakan dari PDAM. Lokasi pengujian dilakukan pada Laboratorium Unit Pelaksanan Teknik Dinas (UPTD) Balai Pengujian Bahan DPU Padang. Pengujian dilakukan terdiri dari uji sifat fisis aggregat asli dan uji sifat mekanis, baik aggregate asli maupun yang telah diberi campuran berbagai variasi semen. Uji sifat fisis terdiri dari ;

Tabel 2. Jenis uji sifat fisis aggregat

\begin{tabular}{|l|l|l|l|}
\hline No & \multicolumn{1}{|c|}{ Jenis Pengujian } & \multicolumn{1}{c|}{ Standar Pengujian } & Jumlah Sampel \\
\hline 1 & Saringan & SNI 1968-1990-F & 1 \\
\hline 2 & Berat Jenis & SNI 03-1964-1990 & 1 \\
\hline
\end{tabular}

Sedangkan uji sifat mekanis terdiri dari ;

Tabel 3. Jenis uji sifat mekanis aggregat

\begin{tabular}{|l|l|l|l|}
\hline No & \multicolumn{1}{|c|}{ Jenis Pengujian } & \multicolumn{1}{|c|}{ Standar Pengujian } & Jumlah Sampel \\
\hline 1 & Pemadatan modified & AASHTO-99-193-74 & 5 \\
\hline 2 & CBR Laboratorium & SNI-1989 & 5 \\
\hline
\end{tabular}

Peralatan yang digunakan antara lain;

1 set saringan standar; 1 set t pemadat modified; 1 set CBR; Alat-alat bantu (timbangan, oven, desicator, dan lain-lain). 
Adapun tahap-tahap pelaksanaan penelitian dapat dilihat pada bagan alir penelitian (Gambar 4).

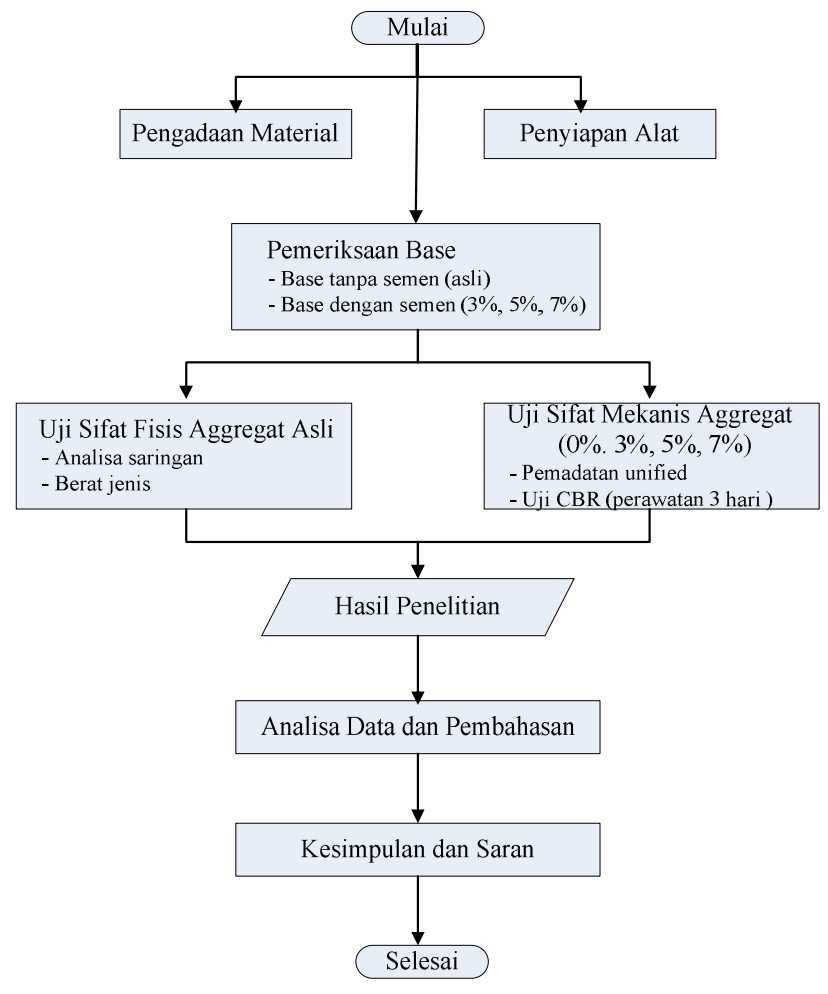

Gambar 4. Bagan alir penelitian

\section{HASIL DAN PEMBAHASAN}

\subsection{Hasil}

Hasil uji sifat fisis aggregat terdiri dari hasil uji berat jenis (specific gravity) (Tabel 4) dan uji saringan (Tabel 5, Tabel 6. Tabel 7 , Tabel 8, dan Tabel 9).

Tabel 4. Hasil uji berat jenis aggregat

\begin{tabular}{|l|l|l|}
\hline No & \multicolumn{1}{|c|}{ Uraian } & \multicolumn{1}{c|}{ Gs } \\
\hline 1 & Aggregat 20 - 30 & 2,69 \\
\hline 2 & Aggregat 10 - 20 & 2,60 \\
\hline 3 & Aggregat 5 - 10 & 2,60 \\
\hline 4 & Abu batu & 2,68 \\
\hline 5 & Semen & 3,15 \\
\hline
\end{tabular}

Tabel 5. Hasil uji analisa saringan

\begin{tabular}{|l|l|l|l|l|l|}
\hline \multirow{2}{*}{$\begin{array}{c}\text { Ukuran } \\
\text { Saringan }\end{array}$} & \multicolumn{5}{|c|}{ \% Lolos } \\
\cline { 2 - 6 } & Agg 20-30 & Agg 10-20 & Agg 5-10 & Abu Batu & Semen \\
\hline $1,5 ”$ & 100 & 100 & 100 & 100 & 100 \\
\hline $1 "$ & 20,40 & 100 & 100 & 100 & 100 \\
\hline $3 / 8 ”$ & & 8,44 & 68,92 & 100 & 100 \\
\hline no.4 & & 0,02 & 8,38 & 98.30 & 80,02 \\
\hline no.10 & & & 1,44 & 66,65 & 63,25 \\
\hline no.40 & & & & 29,16 & 21,91 \\
\hline 200 & & & & 10,74 & 4,17 \\
\hline
\end{tabular}


Tabel 6. Hasil uji saringan dengan komposisi 0\% semen

\begin{tabular}{|l|l|l|}
\hline \multirow{2}{*}{ Ukuran Sringan } & \multicolumn{2}{|c|}{ \% Lolos } \\
\cline { 2 - 3 } & Komposisi Campuran & Spec. Gradasi \\
\hline $1,5 "$ & 100 & 100 \\
\hline $1 "$ & 80,10 & $79-85$ \\
\hline $3 / 8 "$ & 50,47 & $44-58$ \\
\hline no.4 & 36,09 & $29-44$ \\
\hline no. 10 & 23,56 & $17-30$ \\
\hline no.40 & 10,20 & $7-17$ \\
\hline no. 200 & 3,76 & $2-8$ \\
\hline
\end{tabular}

Tabel 7. Hasil uji saringan dengan komposisi 3\% semen

\begin{tabular}{|l|l|l|}
\hline \multirow{2}{*}{ Ukuran Sringan } & \multicolumn{2}{|c|}{ \% Lolos } \\
\cline { 2 - 3 } & Komposisi Campuran & Spec. Gradasi \\
\hline $1,5 "$ & 100 & 100 \\
\hline $1 "$ & 80,10 & $79-85$ \\
\hline $3 / 8 "$ & 51,32 & $44-58$ \\
\hline no.4 & 30,26 & $29-44$ \\
\hline no.10 & 20,03 & $17-30$ \\
\hline no.40 & 10,29 & $7-17$ \\
\hline no. 200 & 5,62 & $2-8$ \\
\hline
\end{tabular}

Tabel 8. Hasil uji saringan dengan komposisi 5\% semen

\begin{tabular}{|l|l|l|}
\hline \multirow{2}{*}{$\begin{array}{c}\text { Ukuran } \\
\text { Sringan }\end{array}$} & \multicolumn{2}{c|}{ \% Lolos } \\
\cline { 2 - 3 } $1,5 "$ & Komposisi Campuran & Spec. Gradasi \\
\hline $1 "$ & 100 & 100 \\
\hline $3 / 8 "$ & 80,10 & $79-85$ \\
\hline no.4 & 53,77 & $44-58$ \\
\hline no. 10 & 34,06 & $29-44$ \\
\hline no.40 & 23,34 & $17-30$ \\
\hline no. 200 & 12,87 & $7-17$ \\
\hline
\end{tabular}

Tabel 9. Hasil uji saringan dengan komposisi $7 \%$ semen

\begin{tabular}{|l|l|l|}
\hline \multirow{2}{*}{ Ukuran Sringan } & \multicolumn{2}{|c|}{ \% Lolos } \\
\cline { 2 - 3 } & Komposisi Campuran & Spec. Gradasi \\
\hline $1,5 "$ & 100 & 100 \\
\hline $1 "$ & 82,49 & $79-85$ \\
\hline $3 / 8 "$ & 41,50 & $44-58$ \\
\hline no.4 & 19,52 & $29-44$ \\
\hline no.10 & 14,03 & $17-30$ \\
\hline no.40 & 9,92 & $7-17$ \\
\hline no. 200 & 7,93 & $2-8$ \\
\hline
\end{tabular}

Hasil uji sifat mekanis terdiri dari hasil uji pemadatan (Tabel 10) dan hasil uji CBR dengan rendaman dan tanpa rendaman dengan masa perawatan 3 hari (Tabel 11)

Tabel 10. Hasil uji pemadatan

\begin{tabular}{|l|l|l|l|}
\hline No. & \multicolumn{1}{|c|}{ Uraian } & \multicolumn{1}{c|}{ W opt $(\%)$} & \multicolumn{1}{c|}{$\gamma_{\mathrm{d} \mathrm{maks}}\left(\mathrm{gr} / \mathrm{cm}^{3}\right)$} \\
\hline 1 & Base & 5,00 & 2,15 \\
\hline 2 & Base + 3\% semen & 5,30 & 2,25 \\
\hline 3 & Base + 5\% semen & 5,51 & 2,22 \\
\hline 4 & Base +7\% semen & 5,65 & 2,18 \\
\hline
\end{tabular}


Tabel 11. Hasil uji CBR dengan rendaman dan tanpa rendaman dengan masa perawatan 3 hari

\begin{tabular}{|l|l|l|l|}
\hline No. & \multicolumn{1}{|c|}{ Uraian } & CBR dengan rendaman (\%) & CBRTanpa rendaman $(\%)$ \\
\hline 1 & Base & 92,90 & 94,50 \\
\hline 2 & Base $+3 \%$ semen & 97,57 & 99,30 \\
\hline 3 & Base $+5 \%$ semen & 96,27 & 98,70 \\
\hline 4 & Base $+7 \%$ semen & 90,20 & 93,63 \\
\hline
\end{tabular}

\subsection{Pembahasan}

\section{Kadar air optimum}

Kadar air optimum meningkat seiring dengan meningkatnya prosentase semen pada base (Tabel 10 dan Gambar 5),

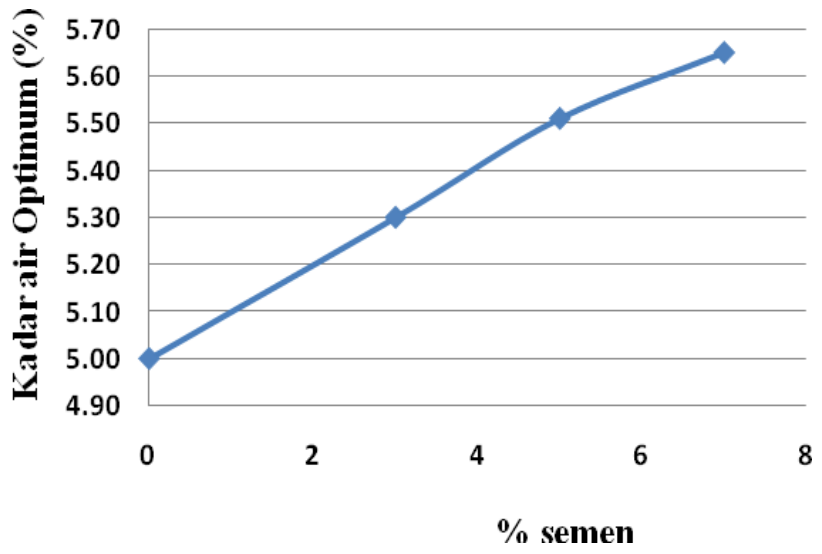

Gambar 5. Pengaruh prosentase semen terhadap nilai kadar air optimum $\left(\mathrm{w}_{\mathrm{opt}}\right)$

Kadar air optimum saat base $+7 \%$ semen $5,65 \%$ terjadi peningkatan sebesar $0,65 \%$ atau $13 \%$ jika dibandingkan dengan kadar air optimum base asli. Peningkatan ini disebabkan karena semen butuh air dalam proses oksidasinya, disamping itu butiran semen yang halus mempunyai permukaan yang luas, sehingga lebih banyak membutuhkan air untuk membasahi seluruh permukaannya.

\section{Kepadatan maksimum ( $\gamma d$ maks)}

Pada pengujian terlihat awalnya nilai kepadatan ini meningkat (base $+3 \%$ semen), pada peningkatan prosentase semen berikutnya, nilai ini cenderung menurun (Tabel 10 dan Gambar 6).

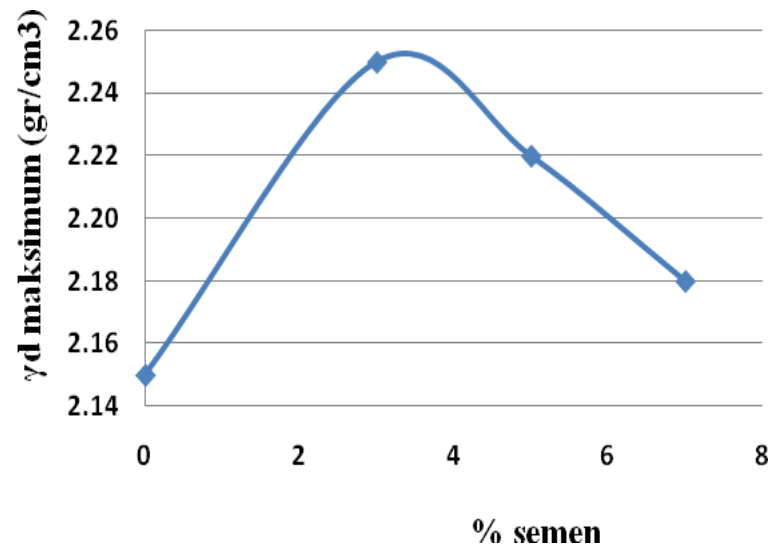

Gambar 6. Pengaruh prosentase semen terhadap nilai kepadatan maksimum ( $\gamma \mathrm{d}$ maks) 
Pada base $+3 \%$ semen terjadi peningkatan $0,10 \mathrm{gr} / \mathrm{cm} 3$ atau $4,65 \%$ dari kepadatan base asli, tetapi saat base $+7 \%$ semen terjadi penurunan, sehingga jika dibandingkan dengan base asli peningkatan hanya $0,03 \mathrm{gr} / \mathrm{cm} 3$ atau $1,395 \%$ dari nilai kepadatan base asli. Penurunan dari nilai kepadatan ini disebabkan karena terjadinya peningkatan kadar air seiring dengan meningkatnya prosentase semen pada base, sehingga pori-pori yang tadinya terisi butiran halus, sekarang sudah ditempati oleh air.

\section{Uji CBR}

Hasil uji CBR tanpa rendaman dan dengan rendaman dengan masa perawatan 3 hari, kedua kondisi ini memperlihatkan pada awalnya nilai-nilai CBR meningkat, seiring dengan peningkatan prosentase semen pada base, kedua nilai CBR ini cenderung menurun (Tabel 11 dan Gambar 7)

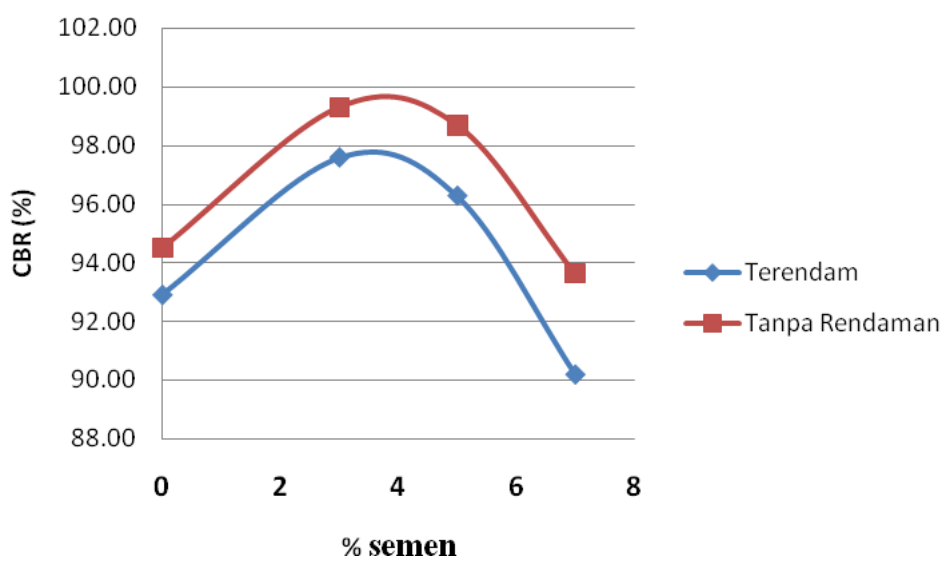

Gambar 7. Pengaruh prosentase semen terhadap nilai CBR Laboratorium

Pada campuran base $+3 \%$ semen, dengan rendaman terjadi peningkatan sebesar 4,67\% atau 5,03\% dari nilai CBR base asli dengan rendaman, sedangkan pada tanpa rendaman terjadi peningkatan sebesar $4,80 \%$ atau sebesar 5,08\% dari nilai CBR base asli tanpa rendaman, pada base $+7 \%$, tanpa rendaman terjadi penurunan sebesar $0,87 \%$ atau $0,92 \%$ dari nilai CBR base asli tanpa rendaman, dengan rendaman terjadi penurunan sebesar 2,70\% atau 2,91\% dari nilai CBR base asli dengan rendaman. Penurunan ini terjadi karena hasil pemadatan yang juga menurunan seiring dengan peningkatan prosentase semen pada base, karena nilai CBR sangat tergantung dari kepadatan tanah.

\section{KESIMPULAN DAN SARAN}

\subsection{Kesimpulan}

Berdasarkan hasil penelitian diperoleh beberapa kesimpulan antara lain ;

1. Pada uji pemadatan, nilai kadar air optimum meningkat seiring dengan meningkatnya prosentase semen pada base, jika dibandingkan dengan nilai kadar air optimum base asli, pada campuran base $+7 \%$ semen, terjadi peningkatan sebesar $0,65 \%$ atau $13 \%$ dari nilai kadar air optimum base asli, sedangkan nilai kepadatan maksimum, pada awalnya nilai ini cenderung meningkat, yaitu pada campuran base $+3 \%$ semen, terjadi peningkatan sebesar $0,10 \mathrm{gr} / \mathrm{cm} 3$ atau $4,65 \%$ dari nilai kepadatan maksimum base asli. Pada peningkatan prosentase semen selanjutnya nilai ini cenderung menurun. Pada campuran base $+7 \%$ semen nilai peningkatan ini hanya $0,03 \mathrm{gr} / \mathrm{cm} 3$ atau $1,395 \%$ dari nilai kepadatan base asli.

2. Hasil uji CBR tanpa rendaman atau dengan rendaman, mengikuti hasil uji kepadatan, pada campuran base $+3 \%$ semen, dengan rendaman terjadi peningkatan sebesar $4,67 \%$ atau $5,05 \%$ dari nilai CBR dengan rendaman base asli. Tanpa rendaman terjadi peningkatan sebesar $4,80 \%$ atau 5,08\% dari nilai CBR base asli tanpa rendaman. Pada peningkatan prosentase semen 
selanjutnya nilai ini cenderung menurun. Pada campuran base $+7 \%$ semen nilai CBR dengan rendaman terjadi penurunan sebesar $2,70 \%$ atau $2,91 \%$ dari nilai CBR base asli dengan rendaman, sedangkan tanpa rendaman terjadi penurunan sebesar $0,87 \%$ atau $0,92 \%$ dari nilai CBR base asli tanpa rendaman.

3. Hasil terbaik dicapai nilai kepadatan, nilai CBR dengan rendaman atau tanpa rendaman adalah pada kondisi campuran base $+3 \%$ semen.

\subsection{Saran}

1. Agar penelitian ini lebih bervariasi maka pada penelitian berikutnya, pengambilan bahan base disarankan diambil pada quary yang berbeda. Hal ini diperlukan karena penyerapan aggregat terhadap air pada masing-masing quary berbeda pula, sehingga diharapkan diperoleh sumber quary yang baik untuk bahan base + semen.

2. Waktu perawatan dicoba lebih besar dari 3 hari, sehingga diharapkan diperoleh waktu perawatan yang lebih baik

\section{DAFTAR KEPUSTAKAAN}

Anonim, 1986, "American Association of State Highway And Transportation Officials (AASHTO)", Washinton DC.

Anonim, 1989, "Annual Book Of ASTM Standard”, Philadelphia.

Bowles, JE., 1986 "Sifat-sifat Fisis dan Geoteknis Tanah", Edisi Kedua, Erlangga Jakarta.

Damoerin D., Ferisdiyanto, 1999 "Stabilisasi Tanah Lempung Ekspansif dan Pasir Dengan Penambahan Semen atau Kapur Untuk Lapisan Badan Jalan”, Prosiding Seminar Nasional Geoteknik 1999, halaman $1-10$

Dep. PU, 1992 "Pedoman Perkerasan Lentur Jalan Raya", Jakarta

Kezdi, A., 1979, "Stabilized Earth Road", Elsvier Scientific Publishing Company, New York

Mitchell, JK., 1992 "Fundamentals of Soil Behavior", second edition, John Wiley \& Sons, Inc, New York.

Naatonis F., Candra I, (1998), "Penggunaan Campuran Tanah Asal Dengan Semen Kupang Sebagai Material Pondasi Jalan di Kupang (NTT)", Skripsi S-1 Teknik Sipil Universitas Kristen Petra, Surabaya.

Rachmansyah A, Dkk, 2008, "Pengaruh Prosentase Pasir Pada Kaolin Yang Dipadatkan Dengan Pemadatan Standar Terhadap Rasio Daya Dukung California (CBR)”, Jurnal Rekayasa Sipil Volume 2 Nomor 3, Universitas Brawijaya Malang.

Sukirman, S, 1992, "Perkerasan Lentur Jalan Raya, Bandung 